\title{
Lack of Association or Linkage Disequilibrium Between Schizophrenia and Polymorphisms in the 5-HT1D $\alpha$ and 5-HT1Dß Autoreceptor Genes: Family-Based Association Study
}

\author{
Alda M. Ambrósio, ${ }^{1 *}$ James L. Kennedy, ${ }^{2}$ Fabio Macciardi, ${ }^{2}$ Isabel Coelho, ${ }^{3}$ Maria J. Soares, ${ }^{3}$ \\ Catarina R. Oliveira, ${ }^{1}$ and Carlos N. Pato ${ }^{4}$ \\ ${ }^{1}$ Center for Neuroscience of Coimbra, Department of Neurochemistry, Faculty of Medicine, University of Coimbra, Coimbra, Portugal \\ ${ }^{2}$ Neurogenetics Section, Center for Addiction and Mental Health, University of Toronto, Toronto, Ontario, Canada \\ ${ }^{3}$ Department of Psychological Medicine, Faculty of Medicine, University of Coimbra, Coimbra, Portugal \\ ${ }^{4}$ Center for Psychiatric and Molecular Genetics, SUNY Upstate Medical University; and Behavioral Health Care Line, VISN 2, \\ Veterans Administration, Syracuse, New York
}

\begin{abstract}
Genetic factors play a major role in the etiology of schizophrenia and disturbances of serotonergic pathways have been implicated in this disorder. The aim of the present study was to examine genetic association between schizophrenia and polymorphisms in the 5-HT1D $\alpha$ (TaqI) and 5HT1Dß (T261G and G861C) autoreceptor genes in ninety trios from Portugal. No association or linkage disequilibrium was obtained between schizophrenia and 5-HT1D $\alpha$ and 5-HT1D $\beta$ autoreceptor genes with both haplotype relative risk (HRR) and transmission disequilibrium test (TDT). Concerning 5-HT1D $\beta$ autoreceptor gene, also negative results was obtained in the analysis of the haplotypes with transmit. Thus, our data provide no support for the hypothesis that polymorphisms at 5-HT1D $\alpha$ (TaqI) and 5-HT1D (T261G and G861C) genes contributes to susceptibility to schizophrenia in the Portuguese population. (c) 2004 Wiley-Liss, Inc.
\end{abstract}

KEY WORDS: candidate genes; serotoninergic system; linkage disequilibrium; haplotypes; Introduction

\section{INTRODUCTION}

Schizophrenia is a major psychiatric disorder. Data from twin, adoption and family studies have clearly demonstrated that genetic factors play an important role in this disease [Riley and McGuffin, 2000]. The most common mode of transmission of schizophrenia probably involves multiple susceptibility loci [Baron, 2001; Prasad et al., 2002], although their number and contribution to develop the disease, and the degree of interaction between them remain unanswered.

Grant sponsor: Medical Research Council of Canada; Grant sponsor: National Institute of the Mental Health of USA; Grant sponsor: Fundação para a Ciência e a Tecnologia, Portugal.

*Correspondence to: Alda M. Ambrósio, Ph.D., Center for Neuroscience of Coimbra, Department of Neurochemistry, Faculty of Medicine, University of Coimbra, 3004-517 Coimbra, Portugal. E-mail: aldachico@yahoo.com

Received 22 February 2003; Accepted 23 December 2003

DOI 10.1002/ajmg.b.30023
Several lines of evidence suggest that a serotonergic dysfunction is involved in the susceptibility to schizophrenia [Kunovac and Stahl, 1995]. Serotonin (5-HT) is involved in a wide variety of sensory, motor, and cortical functions, being particularly relevant in modulating the effects of dopamine [Kapur and Remington, 1996], the first neurotransmitter supposed to be implicated in schizophrenia [Meltzer, 1987; Bleich et al., 1988]. To date, 5 -HT receptors are classified into seven main classes, 5-HT1-7, which can be further divided into different subclasses [see Barnes and Sharp, 1999]. The manner in which 5-HT exerts its regulatory influence on physiological and pathological functions of the central nervous system not only through multiple interactions with other systems, but also through a multiplicity of 5-HT receptor subtypes [see Barnes and Sharp, 1999]. Among many 5-HT receptors subtypes, for example, 5-HT1D receptors are important for schizophrenia because their major function is to control 5-HT release from serotonergic neuron terminals (autoreceptors) in the brain [Barnes and Sharp, 1999]. Cloning studies have revealed two 5-HT1D receptor subtypes, termed 5-HT1D $\alpha$ and 5-HT1D $\beta$ [Hamblin and Metcalf, 1991; Demchyshyn et al., 1992; Weinshank et al., 1992]. The genes for these receptors have been localized to chromosomes 1p36.3-p34.3 and 6q13, respectively [Libert et al., 1991; Jin et al., 1992], and are widely expressed in the human brain [Domenech et al., 1997; Gaster et al., 1998], with the highest levels of receptor expression observed in limbic regions and basal ganglia [Hamblin and Metcalf, 1991; Demchyshyn et al., 1992; Weinshank et al., 1992]. Considering the important role of 5-HT1D $\alpha$ and 5HT1D $\beta$ receptors in the control of serotonin release [Barnes and Sharp, 1999], mutations occurring in the serotonin autoreceptor genes may contribute to the development of schizophrenia by causing altered function of serotonergic neurons. Therefore, polymorphisms such as the silent TaqI polymorphism in the coding region of $5-\mathrm{HT} 1 \mathrm{D} \alpha$ gene, the $\mathrm{T} 261 \mathrm{G}$ polymorphism situated in the $5^{\prime}$-untranslated region and the G861C polymorphism situated in the coding region of HT1D $\beta$ gene may be implicated directly or indirectly through dopaminergic or other systems. In addition, genetic variation might account for interindividual differences in response to drugs acting via serotonergic pathways. In this way, alterations in genes coding for receptor proteins may affect their binding affinities for neuroleptics, the efficiency of signal transduction, or their levels of expression, which may in turn alter the drug's therapeutic action.

Several studies have reported genetic linkage between schizophrenia and markers located on chromosomes 1 and 6 [Hovatta et al., 1999; Hwu et al., 2000; Baron, 2001; Blackwood et al., 2001; Gurling et al., 2001]. Also, support for linkage on 
chromosome 1q21-q22 was obtained with a genome-wide scan for schizophrenia susceptibility loci in 22 affected Canadian families [Brzustowicz et al., 2000]. Although several linkage studies have been performed to localize major effect susceptibility genes for schizophrenia; association studies based on linkage disequilibrium are suitable, since the genetic etiology may be multifactorial or polygenic. Any single susceptibility gene contributes only a small fraction to the overall risk, and allelic variation at such genes must be high, and can be directly evaluated as susceptibility factors using candidate gene association studies [Lander, 1996; Risch and Merikangas, 1996; Collins et al., 1997]. Thus, the best approach to detect genes for susceptibility to schizophrenia is to study homogenous populations by using methods based on linkage disequilibrium, which is a potentially powerful alternative to linkage analysis for detection of minor effect genes possibly implicated in this disorder.

In the present study, we investigated polymorphisms of 5-HT1D $\alpha$ and 5-HT1D $\beta$ autoreceptor genes for susceptibility to schizophrenia in a Portuguese population which is considered highly homogeneous [Schindler et al., 1999].

\section{MATERIALS AND METHODS Sample}

Ninety probands with diagnosis of schizophrenia (58 males and 32 females) and their parents of Portuguese-Caucasian origin were recruited from Azores and Mainland, Portugal. The ascertainment criteria for the study included only one proband with schizophrenia in each family. The age of onset ranged between 15 and 50 years. Local ethical committee approval and written consent from each subject were obtained. Ascertainment and diagnostic methods for the families have been described elsewhere [Pato et al., 2000; Xu et al., 2001]. The sample used in the present study has been partially included in the analyses of other candidate genes [Schindler et al., 2002]. All probands were administered the Diagnostic Interview for Genetics Studies (DIGS) (National Institute of Mental HealthMolecular Genetic Iniciative, 1992) [Nurnberger et al., 1994], Portuguese version [Azevedo et al., 1993] by a clinician with an extensive training in this interview. Data from the DIGS for each subject was compared with medical records and information from close relatives. For each proband, the Operational Criteria (OPCRIT) [McGuffin et al., 1991] checklist was completed, and all were diagnosed according to DSM-IV.

\section{Laboratory Procedures}

Blood samples were collected with EDTA anticoagulant, and genomic DNA was obtained using the standard method [Miller et al., 1988], with slight modifications.

\section{5-Ht1D $\alpha$ Gene Polymorphism}

The silent polymorphism in the coding region of the $5-\mathrm{Ht} 1 \mathrm{D} \alpha$ autoreceptor gene was determined by PCR, using the same conditions described by Ozaki et al. [1995]. Amplification was performed in a final volume of $25 \mu \mathrm{l}$, containing $150 \mathrm{ng}$ genomic DNA as template, $200 \mu \mathrm{M} d N T P s, 0.6 \mu \mathrm{M}$ of each primer, $10 \mathrm{mM}$ Tris- $\mathrm{HCl}(\mathrm{pH}=8.3), 1.5 \mathrm{mM} \mathrm{MgCl}_{2}$, and $1 \mathrm{U}$ of Taq polymerase(Gibco, BRL, Portugal). PCR amplification was initiated at $95^{\circ} \mathrm{C}$ for $5 \mathrm{~min}$ and performed for 30 cycles, each consisting of $95^{\circ} \mathrm{C}$ for $30 \mathrm{sec}, 57^{\circ} \mathrm{C}$ for $30 \mathrm{sec}$, and $72^{\circ} \mathrm{C}$ for 40 sec. PCR products were digested using enzyme TaqI (Biolabs, New England). The digested fragments were separated in $3.5 \%$ agarose gel and were visualized by ethidium bromide staining. Allele frequencies for TaqI 1 and TaqI 2 were 0.966 and 0.034 , respectively.

\section{5-HT1D $\beta$ Gene Polimorphisms}

Two polymorphisms in 5-HT1D $\beta$ gene were examined, one polymorphism situated in the $5^{\prime}$-untranslated region (T261G) and other polymorphism situated in the coding sequence region (G861C). The polymorphism situated in the $5^{\prime}$-untranslated region was carried out by using a PCR-based restriction analysis according to the method described by Nothen et al. [1994], with slight modifications. Standard PCR was carried out in a volume of $25 \mu \mathrm{l}$, containing $150 \mathrm{ng}$ genomic DNA as template, $200 \mu \mathrm{M}$ dNTPs, $10 \mathrm{pmol}$ of each primer, $10 \mathrm{mM}$ Tris$\mathrm{HCl}(\mathrm{pH}=8.3), 1.5 \mathrm{mM} \mathrm{MgCl}_{2}, 0.01 \%$ gelatine and $1 \mathrm{U}$ of Taq polymerase (Perkin Elmer Cetus, Toronto). After initial denaturation at $94^{\circ} \mathrm{C}$ for $5 \mathrm{~min}, 35$ cycles of $\mathrm{PCR}$ reaction were performed under conditions of denaturation at $94^{\circ} \mathrm{C}$, for $20 \mathrm{sec}$, annealing at $61^{\circ} \mathrm{C}$, for $20 \mathrm{sec}$, and extension at $72^{\circ} \mathrm{C}$, for $30 \mathrm{sec}$. Amplification products were digested with $\mathrm{BsmAI}$ restriction enzyme (Biolabs), and separated by electrophoresis in a $3.5 \%$ agarose gel, and visualized with ethidium bromide staining under ultraviolet light. Allele frequencies for G261 and T261 were 0.788 and 0.212 , respectively.

The polymorphism situated in the coding sequence region was genotyped using a modified protocol of the Lappalainen et al. [1995]. Amplification was performed in a final volume of $25 \mu \mathrm{l}$, containing $150 \mathrm{ng}$ genomic DNA as template, $200 \mu \mathrm{M}$ dNTPs, $0.6 \mu \mathrm{M}$ of each primer, $10 \mathrm{mM}$ Tris-HCl $(\mathrm{pH}=8.3)$, $1.5 \mathrm{mM} \mathrm{MgCl}$, and $1 \mathrm{U}$ of Taq polymerase (Gibco, BRL). PCR amplification was initiated at $95^{\circ} \mathrm{C}$ for $5 \mathrm{~min}$ and performed for 30 cycles each consisting of $95^{\circ} \mathrm{C}$ for $30 \mathrm{sec}, 57^{\circ} \mathrm{C}$ for $30 \mathrm{sec}$, and $72^{\circ} \mathrm{C}$ for $40 \mathrm{sec}$. PCR products were digested using enzyme HincII (Biolabs). The digested fragments were separated in $3.0 \%$ agarose gel and were visualized by ethidium bromide staining. Allele frequencies for G861 and C861 were 0.799 and 0.201 , respectively.

\section{Statistical Analysis}

The association studies were performed with ninety nuclear families with one affected (trios), and two strategies were used, the haplotype relative risk (HRR) [Terwilliger and Ott, 1992], and the transmission disequilibrium test (TDT) [Spielman et al., 1993; Spielman and Ewens, 1998], that are robust to population stratification. We used the HRR and TDT to test if the marker locus and the hypothetical disease locus were linked or in linkage disequilibrium. The TDT-STDT programe v 1.1 uses data from heterozygous parents only, and test for individual markers. Furthermore, multiple marker haplotype transmission was performed with program TRANSMIT v 2.5 [Clayton, 1999]. The program TRANSMIT tests for association between markers and disease, examining the transmission of multilocus haplotypes.

\section{RESULTS}

In this study, ninety nuclear families (90 Portuguese schizophrenic patients and their parents) were used. Association studies using case-control approach can generate false positives as a result of population stratification. Indeed, it is difficult to precisely match patients and controls for ethnicity, and differences in allele frequencies between populations could be generating false association. Thus, an elegant and powerful strategy for overcoming this problem is to use the parents of probands and we used the HRR and the TDT methods to test if the marker locus and the hypothetical disease locus were linked or in linkage disequilibrium. The results of HRR and TDT designs of the TaqI polymorphism of the HT1D $\alpha$ gene in the schizophrenic trios are given in Table I. Using these strategies, we found no evidence for association or linkage disequilibrium between the 5 - $\mathrm{HT} 1 \mathrm{D} \alpha$ gene $\left(\mathrm{HRR}, \chi^{2}=0.988\right.$, 
TABLE I. HRR and TDT Results for Taql Polymorphism of 5 -HT1D $\alpha$ in Schizophrenic Trios

\begin{tabular}{lcccc}
\hline & \multicolumn{3}{c}{5 -HT1D $\alpha$ gene } \\
\cline { 3 - 5 } & & \multicolumn{3}{c}{ Not } \\
& & Passed & passed & $\chi^{2}(\mathrm{df}=1), P$-value \\
\hline HRR & Allele 1 & 174 & 169 & $\chi^{2}=0.988, P=0.320$ \\
& Allele 2 & 6 & 11 & \\
TDT & Allele 1 & 9 & 4 & $\chi^{2}=1.923, P=0.166$ \\
& Allele 2 & 4 & 9 & \\
\hline
\end{tabular}

$\mathrm{df}=1, \quad P=0.320 ; \quad$ TDT $\left., \quad \chi^{2}=1.923, \quad \mathrm{df}=1, \quad P=0.166\right) \quad$ and schizophrenia.

The T261G and G861C polymorphisms in the $5^{\prime}$-untranslated and coding regions, respectively, at the 5-HT1D $\beta$ were investigated and the results of HRR and TDT analysis for the RFLPs markers individually are shown in Table II. Using the HRR design, no significant differences were observed between passed and non-passed alleles for both polymorphisms of the 5HT1D $\beta$ gene (HRR of the T261G variant, $\chi^{2}=0.000, \mathrm{df}=1$, $P=1.000 ; \mathrm{HRR}$ of G861C variant, $\left.\chi^{2}=0.264, \mathrm{df}=1, P=0.607\right)$. Similarly, TDT analysis yielded non-significant $P$-values for association of 5-Ht1D $\beta$ polymorphisms and schizophrenia (TDT of the T261G variant, $\chi^{2}=0.333, \mathrm{df}=1, P=0.56$; TDT of G861C variant, $\chi^{2}=0.040, \mathrm{df}=1, P=0.841$; see Table II). In addition with TRANSMIT, we estimated the haplotype frequencies of the two markers in the 5-Ht1D $\beta$ gene, and a total of four haplotypes were detected, with one common haplotype of $65.5 \%$ (Table III). Also with TRANSMIT, we analyzed haplotypes of paired markers for transmission disequilibrium, and the results indicated no evidence for linkage disequilibrium (Table III).

\section{DISCUSSION}

The serotonergic system, which is thought to mediate various physiological and psychological conditions related to certain disease state, including eating disorders, obsessive compulsive disorders, bipolar disorder, and schizophrenia, has been the subject of much research in psychiatric genetics. Because for schizophrenia, 5-HT function could be particularly important in modulating the effects of dopamine, we have chosen a candidate gene from serotonergic system for search schizophrenia susceptibility genes. Using association studies, we have found no evidence for association or linkage disequilibrium of the polymorphism at the $5-\mathrm{HT} 1 \mathrm{D} \alpha$ to schizophrenia. These results obtained with two powerful strategies of

TABLE II. HRR and TDT Results for G261T and G861C Polymorphisms of 5-HT1D $\beta$ in Schizophrenic Trios

\begin{tabular}{lrrrl}
\hline & & \multicolumn{3}{c}{5 -HT1D $\beta$ gene } \\
\cline { 3 - 5 } & & \multicolumn{3}{c}{ Not } \\
& & Passed & passed & $\chi^{2}(\mathrm{df}=1), P$-value \\
\hline HRR & (1) G261 & 142 & 143 & $\chi^{2}=0.000, P=1.000$ \\
& T261 & 38 & 37 & \\
& (2) G861 & 144 & 139 & $\chi^{2}=0.264, P=0.607$ \\
TDT & C861 & 36 & 41 & \\
& (1) G261 & 7 & 5 & $\chi^{2}=0.333, P=0.563$ \\
& T261 & 5 & 7 & \\
& (2) G861 & 13 & 12 & $\chi^{2}=0.040, P=0.841$ \\
& C861 & 12 & 13 & \\
\hline
\end{tabular}

TABLE III. Estimated Haplotype Probabilities and Transmission of Multi-Marker Haplotypes at the 5-HT1D $\beta$ Gene Using TRANSMIT

\begin{tabular}{lrcccc}
\hline Haplotypes & Obs & Exp & O-E & Frequency & $\begin{array}{c}\text { Haplotypic } \\
P \text {-value }\end{array}$ \\
\hline $1-1$ & 121 & 118 & 14 & 0.655 & 0.423 \\
$2-1$ & 21 & 24.5 & 10.75 & 0.136 & 0.286 \\
$1-2$ & 23 & 23.5 & 7.75 & 0.130 & 0.858 \\
$2-2$ & 15 & 14 & 5.5 & 0.077 & 0.671 \\
\hline
\end{tabular}

association (HRR and TDT) indicate that a TaqI polymorphism in the 5 -HT1D $\alpha$ gene is unlikely to be involved in schizophrenia, in our sample, although association in case-controls from Portuguese population has been reported [Coelho et al., 1997]. However, association studies with case-controls can generate false positives as a result of population stratification. This problem can be addressed by the use of nuclear families (trios) based association methods [Ott, 1989; Terwilliger and Ott, 1992; Schaid and Sommer, 1994], which we used in the present work. Similarly, no evidence for association or linkage disequilibrium was found at the individual alleles or their haplotypes of the polymorphisms in $5^{\prime}$-untranslated and coding regions of the 5-HT1D $\beta$ gene and schizophrenia. Our findings are in agreement with case-controls association study in the Portuguese population [Coelho et al., 1997] and linkage study in the Canadian population [Sidenberg et al., 1993]. However, the present results disagree with previous reports that provided evidence supporting linkage in chromosomal regions of the chromosome 6 in other populations [Martinez et al., 1999; Hwu et al., 2000; Baron, 2001]. The differences between these studies reflect heterogeneity and that the $6 \mathrm{p}$ locus could be more important in some geographical populations. There might be a gene on chromosome 6 in which mutations increased the risk of schizophrenia in other populations, but not in the Portuguese population. The discrepancy of the results reflects the importance of the use of more homogeneous populations. The size of this sample was small, which is a limitation of this work. However, family-based association studies are more robust than traditional casecontrol association analysis, as the latter often results in spurious findings due to ethnic stratification. This was the reason why we opted for a family-based association study, which may render the collection of suitable samples more difficult, but is robust against ethnic stratification. Parental chromosomes not transmitted to affected individuals are an ideal control group, because they are the same ethnic origin as the affected individual alleles. Overall, the results of the association studies employed here provide some assurance to exclude a main involvement of the two polymorphisms at the 5HT1D $\beta$ gene in the etiology of schizophrenia, in our sample. However, failure to detect association or linkage disequilibrium between the two polymorphisms in this gene cannot exclude the possibility that there might be another mutations in this gene that play a role in schizophrenia. In addition, it is still also possible that the interaction with other genes is more relevant. Indeed, serotonin has a direct influence on the cholinergic and gabaergic system, and some of serotonin effects on the dopamine system may be mediated, indirectly, through its modulation of the gabaergic and cholinergic system [Powers, 1999]. Future studies should determine whether these variants are associated with other disease phenotypes and/or are of pharmacogenetic relevance. The ability to subdivide the syndrome into more homogenous clinical subtypes will help in identifying etiological factors. DNA typing together 
with cognitive, phenomenological and neuropsychological criteria may define more homogenous subtypes.

In conclusion, we find no support in our family-based association study for a role of the investigated 5-HT1D $\alpha$ and 5 -HT1D $\beta$ polymorphism genes in susceptibility to schizophrenia in the Portuguese population.

\section{REFERENCES}

Azevedo MH, Dourado A, Valente J, Macedo A, Coelho I, Pato M, Pato C. 1993. The Portuguese-Language version of diagnostic interview for genetic studies. Psychiatr Genet 3:189.

Barnes NM, Sharp T. 1999. A review of central 5-HT receptors and their function. Neuropharmacology 38:1083-1152.

Baron M. 2001. Genetics of schizophrenia and the new millennium: Progress and pitfalls. Am J Hum Genet 68:299-312.

Blackwood DHR, Fordyce A, Walker MT, Clair DM, Porteous DJ, Muir WJ 2001. Schizophrenia and affective disorders-cosegregation with a translocation at chromosome 1q42 that directly disrupts brainexpressed genes: Clinical and P300 findings in a family. Am J Hum Genet 69:428-433.

Bleich A, Brown S, Kahn R, Van Pragg H. 1988. The role of serotonin in schizophrenia. Schizophr Bull 14:297-315.

Brzustowicz LM, Hodgkinson KA, Chow EWC, Honer WG, Bassett AS. 2000. Location of a major susceptibility locus for familial schizophrenia on chromosome 1q21-q22. Science 288:678-682.

Clayton D. 1999. A generalization of the transmission/disequilibrium test for uncertain-haplotype transmission. Am J Hum Genet 65:1170 1177.

Coelho I, Macedo A, Valente J, Dourado A, Ambrósio A, King N, Azevedo MH, Kennedy JL, Pato CN, Pato MT. 1997. Association study of serotonin receptors and schizophrenia in a portuguese population. Psiquiatria Clínica 18:41-47.

Collins FS, Guyer MS, Chakravarti A. 1997. Variations on the theme: Cataloging human DNA sequence variation. Science 278:1580-1581.

Demchyshyn L, Sunahara R, Miller K, Teitler M, Hoffman BJ, Kennedy JL, Seeman P, Van Tol HHM, Niznik HB. 1992. A human serotonin 1D receptor variant (5HT1D $\beta$ ) encoded by an intronless gene on chromosome 6. Proc Natl Acad Sci USA 89:5522-5526.

Domenech T, Beleta J, Palacios JM. 1997. Characterization of human serotonin 1D and $1 \mathrm{D}$ receptors using $\left[{ }^{3} \mathrm{H}\right]-\mathrm{GR}-125743$, a novel radiolabelled serotonin $5 \mathrm{HT} 1 \mathrm{D} / 1 \mathrm{~B}$ receptor antagonist. Naunyn-Schmiedeberg's Arch Pharmacol 356:328-334.

Gaster LM, Blaney FE, Davies S, Duckworth DM, Ham P, Jenkins S, Jennings AJ, Joiner GF, King FD, Mulholland KR, Wyman PA, Hagan JJ, Hatcher J, Jones BJ, Middlemiss DN, Price GW, Riley G, Roberts C Routledge C, Selkirk J, Slade PD. 1998. The selective 5-HT1B receptor inverse agonist $1^{\prime}$-methyl-5-[[2'-methyl-4'-(5-methyl-1,2,4-oxadiazol3-yl)biphenyl-4-yl]carbonyl]-2,3,6,7-tetrahydro-spiro[furo[2,3-f]indole3,4'-piperidine] (SB-224289) potently blocks terminal 5-HT autoreceptor function both in vitro and in vivo. J Med Chem 41(8):1218-1235.

Gurling HM, Kalsi G, Brynjolfson J, Sigmundsson T, Sherrington R, Mankoo BS, Read T, Murphy P, Blaveri E, McQuillin A, Petursson H, Curtis D. 2001. Genomewide genetic linkage analysis confirms the presence of susceptibility loci for schizophrenia, on chromosome 1q32.2, 5q33.2, and 8p21-22 and provides support for linkage to schizophrenia, on chromosomes 11q23.3-24 and 20q12.1-11.23. Am J Hum Genet 68: $661-673$.

Hamblin MW, Metcalf MA. 1991. Primary structure and functional characterization of a human 5T1D-type serotonin receptor. Mol Pharmacol 40:143-148

Hovatta L, Varilo T, Suvisaari J, Terwilliger JD, Ollikainen V, Arajarvi R, Juvonen H, Kokko-Sahin M-L, Vaisanen L, Mannila H, Lonnqvist J, Peltonen L. 1999. A genomewide screen for schizophrenia genes in a isolated Finnish subpopulation, suggesting multiple susceptibility loci. Am J Hum Genet 65:1114-1124.

Hwu H-G, Lin M-W, Lee P-C, Lee F-C, Ou-Yang W-C, Liu C-M. 2000. Evaluation of linkage of markers on chromosome $6 \mathrm{p}$ with schizophrenia in Taiwanese families. Am J Med Genet 96:74-78.

Jin H, Oksenberg D, Askhenazi A, Peroutka SJ, Duncan AMV, Rozmahel R Yang Y, Mengod G, Palacios JM, O’Dowd BF. 1992. Characterization of human 5-hydroxytryptamine ${ }_{1 \mathrm{~B}}$ receptor. J Biol Chem 267:57355738
Kapur S, Remington G. 1996. Serotonin-dopamine interaction and its relevance to schizophrenia. Am J Psychiatry 153(4):466-476.

Kunovac JL, Stahl SM. 1995. Biochemical pharmacology of serotonin receptor subtypes: Hypotheses for clinical applications of selective serotonin ligands. Int Rev Psychiatry 7:55-67.

Lander ES. 1996. The new genomics: Global views of biology. Science 274: 1594-1595

Lappalainen J, Dean M, Charbonneau L, Virkkunen M, Linnoila M, Goldman D. 1995. Mapping of the serotonin 5-HT1D $\beta$ autoreceptor gene on chromosome 6 and direct analysis for sequence variants. Am J Med Genet 60:157-161.

Libert F, Passage E, Parmentier M, Simons MJ, Vassart G, Mattei MG 1991. Chromosomal mapping of A1 and A2 adenosine receptors, VIP receptor, and a new subtype of serotonin receptor. Genomics 11:225227.

Martinez M, Goldi L, Cao Q, Zhang J, Sanders AR, Nancarrow DJ, Taylor JM, Levinson DF, Kirby A, Crowe RR, Andreasen NC, Black DW, Silverman JM, Lennon DP, Nertney DA, Brown D, Mowry BJ, Gershon ES, Gejman PV. 1999. Follow-up study on a susceptibility locus for schizophrenia on chromosome 6q. Am J Med Genet 83: $337-343$.

McGuffin P, Farmer AE, Harvey JL. 1991. A polydiagnostic application of the operational criteria in studies of psychotic illness. Arch Gen Psychiatry 48:764-770.

Meltzer HY. 1987. Biological studies in schizophrenia. Schizophr Bull 13:77-111.

Miller SA, Dykes DD, Plesky HF. 1988. A simple salting out procedure for extracting DNA from human nucleated cells. Nucleic Acids Res $16: 1215$.

Nothen MM, Erdmann J, Shimron-Abarbanell D, Propping P. 1994 Identification of genetic variation in the human serotonin $1 \mathrm{D} \beta$ receptor gene. Biochem Biophys Res Commun 205(2):1194-1200.

Nurnberger JL, Blehar MC, Kaufmann CA, York-Cooler C, Simpson S, HarKavy-Friedman J, Severe J, Malaspina D, Reich T. 1994. Collaborators from NIMH Genetics Initiative. Diagnostic Interview for Genetics Studies. Rationale, unique features, and training. Arch Gen Psychiatry 51:849-859.

Ott J. 1989. Statistical properties of the haplotype relative risk. Genet Epidemiol 6:127-130.

Ozaki N, Lappalainen J, Dean M, Virkkunen M, Linnoila M, Goldman D 1995. Mapping of the serotonin 5-Ht1D $\alpha$ autoreceptor gene (HTR1D) on chromosome 1 using a silent polymorphism in the coding region. Am J Med Genet 60:162-164.

Pato CN, Macedo A, Ambrosio A, Vincent JB, Bauer A, Schindler K, Xu J, Coelho I, Dourado A, Valente J, Azevedo MH, Kennedy JL, Pato MT. 2000. Detection of expansion regions in Portuguese bipolar families. Am J Med Genetic 96:854-857.

Powers RE. 1999. The neuropathology of schizophrenia. J Neuropathol Exp Neurology 58:679-690.

Prasad S, Semwal P, Deshpande S, Bhatia T, Nimgaonkar VL, Telma BK 2002. Molecular genetics of schizophrenia: Past, present and future. J Biosci 27:35-52.

Riley BP, McGuffin P. 2000. Linkage and association studies of schizophrenia. Am J Med Genet 97:23-44.

Risch N, Merikangas K. 1996. The future of the genetic studies of complex human disease. Science 273:1516-1517.

Schaid DJ, Sommer SS. 1994. Comparison of statistics for candidate-gene association studies using cases and parents. Am J Hum Genet 55: $402-409$.

Schindler K, Torre C, Bauer A, Medeiros H, Carvalho C, Fernandes LF, Pato MT, Pato CN. 1999. Identification of a highly homogenous population for genetic study of psychiatric disorders. CNC Spectrums 4(5): $22-24$.

Schindler KM, Pato MT, Dourado A, Macedo A, Azevedo MH, Kennedy JL Pato CN. 2002. Association and linkage disequilibrium between a functional polymorphism of the dopamine-2 receptor gene and schizophrenia in a genetically homogeneous Portuguese population. Mol Psychiatry 7(9):1002-1005.

Sidenberg DG, Basset AS, Demchyshyn L, Niznik HB, Macciardi F, Kamble AB, Honer WG, Kennedy JL. 1993. New polymorphism for human serotonin $1 \mathrm{D}$ receptor variant $(5-\mathrm{HT} 1 \mathrm{D} \beta)$ not linked to schizophrenia in five canadian pedigrees. Hum Hered 43:315-318. 
Spielman RS, Ewens WJ. 1998. A sibship test for linkage in the presence of association: The sib transmission/disequilibrium test. Am J Hum Genet 62:450-458.

Spielman RS, McGinnis RE, Ewens WJ. 1993. Transmission test for linkage desequilibrium: The insulin gene region and insulin-dependent diabetes mellitus (IDDM). Am J Hum Genet 52:506-516.

Terwilliger JD, Ott J. 1992. A haplotype based haplotype relative risk approach to detecting allelic associations. Hum Hered 42:337-346.
Weinshank RL, Zgombick JM, Maccihi MJ, Branchek TA, Harting PR. 1992. HT1D $\alpha$ and 5-HT1D $\beta$. Proc Natl Acad Sci USA 89:3630-3634.

Xu J, Pato MT, Torre CD, Medeiros H, Carvalho C, Basile VS, Bauer A Dourado A, Valente J, Soares MJ, Macedo A, Coelho I, Ferreira CP, Azevedo MH, Macciardi F, Kennedy JL, Pato CN. 2001. Evidence for linkage disequilibrium between the alpha 7-nicotinic receptor gene (CHRNA7) locus and schizophrenia in Azores families. Am J Med Genet 105:669-674. 